\title{
ENERGY AND EXERGY ANALYSIS OF SUGARCANE INDUSTRY USING FREE SIMULATOR
}

\begin{abstract}
A. L. Vieira ${ }^{a}$,
L. F. Lima ${ }^{a}$, W. A. S. Conceiçãob and C. M. G. Andrade

${ }^{a}$ Universidade Tecnológica Federal do Paraná Coordenação de Engenharia Química

Av. dos Pioneiros, 3131

CEP. 86036-370, Londrina, Paraná, Brasil lopesvieira@utfpr.edu.br

${ }^{\mathrm{b}}$ Universidade Estadual de Maringá

\section{ABSTRACT}

Due to environmental and economic problems, we need to seek and investigate renewable energy sources. Worldwide, we have a predominant use of energy derived from fossil fuels. In Brazil, much of the energy comes from hydroelectricity. However, it is known that to be dependent predominantly from a main source, could cause logistical problems. A solution to this situation, in Brazil, are sugarcane plants. These plants are normally self-sufficient in terms of energy, but they can still have their energetic and exegetics efficiencies increased. This paper intends to present by simulation (using free software, COCO) that if all machines in the process, steam-powered, were replaced by machines powered by electricity, the yield should increase. We also show that if we replace the turbines by other, working in higher pressures, the energy will have an even greater increase.
\end{abstract} Departamento de Engenharia Mecânica Av. Colombo, 5790 Bloco 104

Maringá, Paraná, Brasil ${ }^{\mathrm{c}}$ Universidade Estadual de Maringá Departamento de Engenharia Química Av. Colombo, 5790 Bloco D90 Maringá, Paraná, Brasi

Received: February 02, 2016 Revised: May 04, 2016

Accepted: June 06, 2016
Keywords: energy assessment, biomass, simulation, sugarcane, exergy, $\mathrm{COCO}$

\section{NOMENCLATURE}

E energy in system, $\mathrm{kJ}$

$\dot{Q}$ rate of heat transfer, $\mathrm{kJ} / \mathrm{s}$

$\dot{W} \quad$ rate of mechanical power, $\mathrm{kJ} / \mathrm{s}$

$\dot{m}$ rate of mass, $\mathrm{kg} / \mathrm{s}$

$\mathrm{h} \quad$ specific enthalpy, $\mathrm{kJ} / \mathrm{kg}$,

$\mathrm{V}$ speed, $\mathrm{m} / \mathrm{s}$

$\mathrm{g}$ gravitational acceleration, $\mathrm{m} / \mathrm{s}^{2}$

$\mathrm{z}$ height, $\mathrm{m}$

$\mathrm{S} \quad$ entropy in system, $\mathrm{kJ} / \mathrm{K} . \mathrm{s}$

s specific entropy, $\mathrm{kJ} / \mathrm{kg} . \mathrm{K}$

$\mathrm{H}$ enthalpy, $\mathrm{kJ} / \mathrm{kg}$

$\mathrm{T}$ temperature, $\mathrm{K}$

$\mathrm{t}$ time, $\mathrm{s}$

\section{Greek symbols}

$\begin{array}{ll}\psi & \text { exergy, } \mathrm{kJ} / \mathrm{kg} \\ \eta & \text { efficiency, \% } \\ \eta_{\psi} & \text { exergetic efficiency, \% }\end{array}$

$$
\begin{array}{ll}
\begin{array}{l}
\text { in } \\
\text { out }
\end{array} & \text { inlet } \\
\text { outlet } & \text { generation } \\
0 & \text { state } 0 \\
1 & \text { state } 1 \\
2 & \text { state } 2 \\
\text { rev } & \text { reversible } \\
\text { isen } & \text { isentropic }
\end{array}
$$

\section{INTRODUCTION}

Obtaining electricity from a renewable source is crucial for the sustainability of the environment. However, as shown in Fig. 1, indicate that $57.3 \%$ of all energy generated in the signatory countries of the International Energy Agency comes from fossil fuels, $19.0 \%$ comes from nuclear power, $14.9 \%$ hydroelectric, and just. 8.8\% comes from geothermal, solar, wind and other energy sources. (Available:http://www.iea.org/statistics/relatesurveys/ monthlyelectricitysurvey/ and accessed on 20/06/2016).

\section{Subscripts}




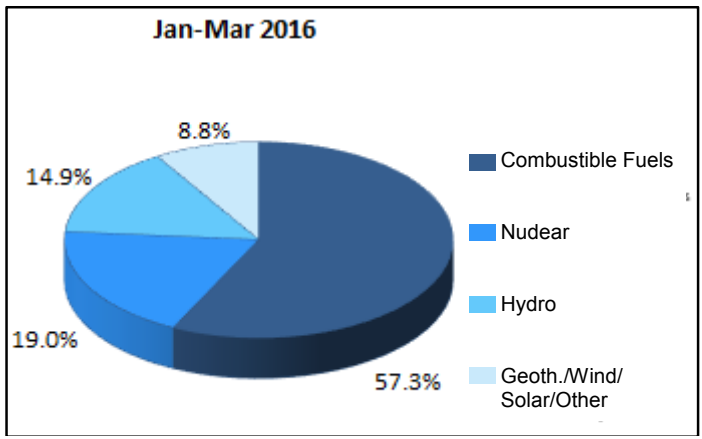

Figure 1. Energy sources in the groups participating in the IEA.

This strong dependence on only one source of energy is also found in Brazil. According to data collected, indicates that the hydraulic source in 2014, represent $65.2 \%$ of all electricity produced in Brazil, as can be seen by Fig. 2. (Available in https://ben.epe.gov.br/downloads/Relatorio_Final B EN_2015.pdf and accessed on 20/06/2016). In this scenario, it is noticed the necessity of a better distribution of investments and more research in the area, in order to obtain a balanced distribution of different energy sources.

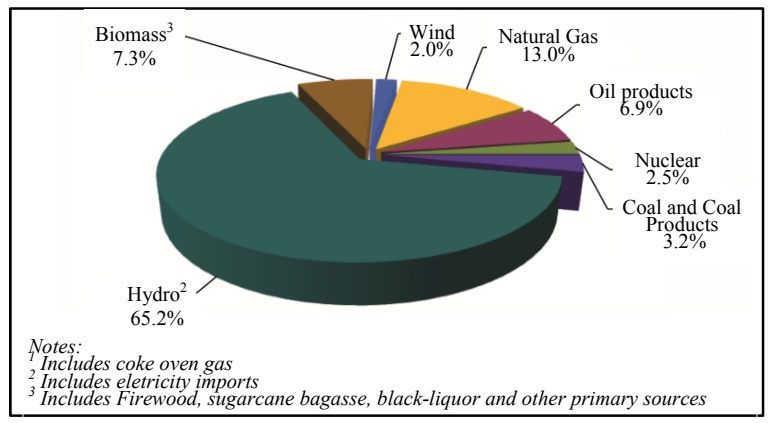

Figure 2. Internal Supply of Electrical Energy by sources in Brazil.

A possible solution found in Brazil are sugarcane plants, once these industries are selfsufficient in terms of energy, using bagasse from sugar cane as fuel in cogeneration systems for the production of thermal, mechanical and electrical energy, necessary to the production process. Through a correct energy integration process, it is possible to generate a surplus of electricity to inject into the local distribution system. This possibility of selling surplus electricity has led sugarcane plants to improve their production technologies, in order to reduce energy consumption and maximize the electricity generated by the plant. This measure has as a result, excess electricity, which reach two thirds of the power generated (Neto, 2001).

During the past ten years, the Brazilian sugarcane industry has shown great potential in power generation contributing $7.2 \mathrm{GW}$ to the national energy grid, which corresponds to $5.8 \%$ of all energy matrix in operation, with a growth outlook of $17 \mathrm{GW}$ of installed power capacity up to 2015/2016. This power is greater when compared to the nominal power of Itaipu Hydroelectric Power Plant, the second largest hydropower plant in the world. (Available in http://www.unica.com.br/dados Cotacao/estatistica/, and Accessed on 03/10/2012).

The sugarcane plants in Brazil, despite being self-sufficient in energy terms, are not working at peak efficiency, and there are few academic and scientific works with this approach.

There are studies related to the application of process simulation in the sugarcane industry, and in most of them the focus is to optimize the process of sugar and ethanol in the reduction of steam consumption and, in a few cases, simulation is performed in the production process and steam consumption.

Within this scenario, this paper aims to use a tool for simulating the energy process of sugarcane industry to show the feasibility of using heat engines, replacement and increase in vapour pressure used in the process. The software used is the COCO, a simulator of processes to stationary state, modular and free, based on the CAPE OPEN system. This software will perform simulation based on information (Fiomari, 2004) in the current plan, the replacement of all heat engines by just one at the same vapour pressure and another on a higher pressure.

\section{THEORY}

The conversion of thermal energy to work was the most interest since a first in thermodynamics studies.

$$
\begin{aligned}
\frac{d E}{d t}=\dot{Q}-\dot{W}+ & \sum_{\text {in }} \dot{m}\left(h+\frac{1}{2} V^{2}+g z\right) \\
& -\sum_{\text {out }} \dot{m}\left(h+\frac{1}{2} V^{2}+g z\right)
\end{aligned}
$$

Where:

Rate of energy in system, $\left(\frac{d E}{d t}\right)$

Rate of heat transfer $(\dot{Q})$

Rate of mechanical power $(\dot{W})$

Specific enthalpy (h)

Speed $(V)$

Gravitational acceleration $(g)$

Height ( $z)$.

But from the first half of XIX century that the principles of conservation and conversion have been established, resulting in the first law of Thermodynamics represented by the energy balance describe as it is shown in Eq. (1).

Based only on the first law of thermodynamics can guess that it are a simple and direct process, but real data evidence that a transfer full of heat to work isn't possible. 


$$
\eta=\frac{\dot{W}}{\dot{Q_{1}}}=\left(1-\frac{\dot{Q_{2}}}{\dot{Q_{1}}}\right)
$$

The energy efficiency ( $\eta$ ) in any thermal system yield work is a ratio between energy entering in the process in the form of heat and the work produced as it is shown in Eq. 2.

As always there is a lost energy $\left(\dot{Q}_{2}\right)$, the second term in an equation never isn't zero and the efficiency of machine, in spite of all ideality, is less the $100 \%$.

From the second law of thermodynamic, arise concept of entropy, variable that show the possibility of combination of possible probabilistic states. All irreversibility of process, can be measure, in terms of entropy of generation (Bejan, 1988), a variable that depend the path and is positive algebraically. Its main causes are associate to friction, not resisted expansion, heat exchange with finite temperature difference, hysteresis effects, electrical losses, mixture of different substances, combustion (Moran \& Shapiro, 2002).

$$
S_{g e r}=\frac{d \dot{S}}{d t}-\sum_{i} \frac{\dot{Q}_{i}}{T_{i}}+\sum_{\text {out }} \dot{m} \cdot s-\sum_{\text {in }} \dot{m} \cdot s
$$

Where:

Rate of variation of system's variation, $\left(\frac{d \dot{S}}{d t}\right)$

Absolut temperature, $(T)$

Specific entropy, $(s)$

Irreversible process produces entropy and this production is proportional to effect of irreversible in the system. The calculation of entropy of generation can be realized as it is shown in Eq. 3 .

The productivity or isentropic efficiency is the ratio between the real produced work to side of system and the work that would have been achieved if the process between the same input state and the same outlet pressure had been isentropic.

This efficiency is able to evaluate how irreversible is the process, but isn't able to identify the possible causes of irreversibility.

\section{Exergetic efficiency}

It is understood by exergy $\psi$ maximum work that can be obtained when a quantity of material is led through a reversible process from the initial state specified up to the state of thermodynamic equilibrium with the environment.

$\psi_{1}=\left(H_{1}-H_{0}\right)-T_{0} \cdot\left(S_{1}-S_{0}\right)+Q_{1} \cdot\left(1-\frac{T_{0}}{T_{1}}\right)$

Where:
$H_{1}$ : enthalpy of the fluid in the state $1, H_{0}$ : enthalpy of the fluid at ambient conditions, $S_{1}$ : entropy of the fluid in the state $1, S_{0}$ : entropy of the fluid at ambient conditions, $Q_{1}$ : heat exchanged in volume of control, $T_{1}$ : volume of control temperature in state $1, T_{0}$ : room temperature.

This thermodynamic equilibrium between the volume of control and environment is commonly known as dead state and no work is produced by a volume of control in the dead state. Neglecting the nuclear, magnetic and surface tension effects, the exergy consists on the physical energy, kinetic, potential and chemical in Eq. 4 shows.

$$
\begin{gathered}
\Delta \psi=W_{\text {rev }}=\left(H_{2}-H_{1}\right)-T_{0} \cdot\left(S_{2}-S_{1}\right) \\
+\sum Q_{i} \cdot\left(1-\frac{T_{i}}{T_{0}}\right)
\end{gathered}
$$

Generally, for a device, which starts in state 1 and goes to state 2 , it is possible to calculate the maximum energy that the system can perform as the variation of exergy as it is shown in Eq. 5 .

The variation of exergy can be called of reversible work for equipment between state 1 and 2 $W_{\text {rev }}$.

$$
\eta_{\psi}=\frac{W}{W_{\text {rev }}}
$$

The term exergy efficiency, $\eta_{\psi}$, or commonly called at the basic books of Thermodynamics, as efficiency of the $2^{\text {nd }}$ Law of Thermodynamics, the ratio of the work achieved on the machine and the maximum useful work that it can do at the same in reverse conditions, as it is shown in Eq. 6.

The exergetic efficiency is always higher than isentropic because some of idealizations were disregarded.

\section{COCO Simulator}

Simulations can use traditional languages such as FORTRAN, C, MATLAB or MAPLE. There are specific software for process simulation, and they may be private or free. The use of free simulators is more widespread because it is easy to obtain (no charge) and due to the simple implementations in the code (open source). COCO is a process simulator for steady state, modular, free of charge, based on CAPE OPEN system. (Available in: http://www.cocosimulator.org and accessed on 28/02/2016).

CAPE is the abbreviation of Computer Aided Process Engineering, which means engineering processes assisted by computer. COCO stands for CAPE-OPEN to CAPE-OPEN that is a program with allows standardized communication between simulators and other products developed by third parties. The components present in the COCO are COFE, TEA, COUSCOUS, and CORN. 
COFE (CAPE-OPEN Flowsheeting Environment) is a flowchart environment that allows visual interface, in other words, an intuitive interface flowcharts of industrial plants with the user. It allows display of current properties and can use a unit operation.

Researchers are using the COCO for the chemical industry, however, there are few uses of $\mathrm{COCO}$ in Brazilian sugar energy plants.

\section{MATERIALS AND METHODS}

The hardware used was an HP branded computer with Intel ${ }^{\circledR}$ Core ${ }^{\mathrm{TM}}$ i7-2670QM processor CPU GHz 2:20.

COCO Simulator software was used to simulate the energy process units in sugarcane plants and has the characteristic of being a free software. This software works by performing simulations in a stationary environment flowchart (COFE). In this work, the version used for $\mathrm{COCO}$ was 3.1 and for COFE was version 3.1.0.2 (x64). COCO components used were of flowcharts, thermodynamic package and package unit operations. The operating system was Windows 10 Pro.

\section{EXPERIMENTS}

(Fiomari, 2004) was held an energy and exergy analysis in a sugarcane plant, where the plant consisted of two steam generators with the steam production capacity of 70 to $50 \mathrm{ton} / \mathrm{h}$, with inlet pressure of $3.0 \mathrm{MPa}$ and temperature of $105^{\circ} \mathrm{C}$. The processes that used steam were the chopper, shredder, milling and electric power generators. Through the data of temperature and pressure at the turbine inlet and outlet of each device, Fiomari were calculated the energetic and exegetic efficiencies. Based on this information, this study conducted with the same data and configuration of Fiomari, it is shown in Fig. 3 and Table 1, the simulation on the software COCO.

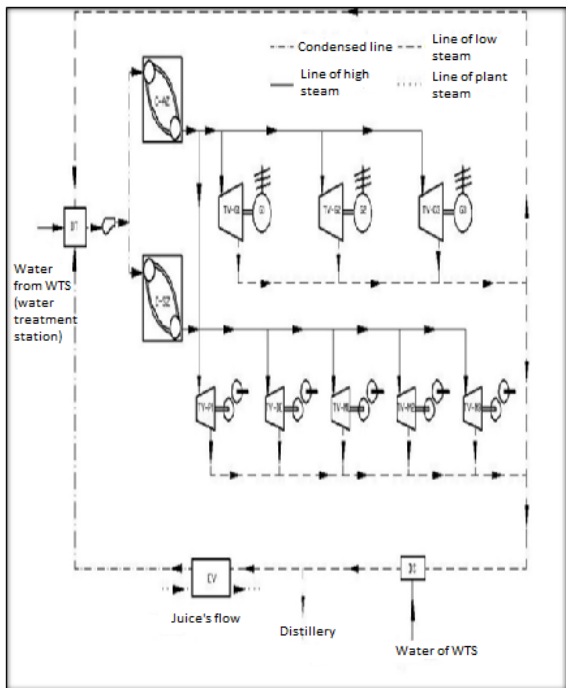

Figure 3. Flowchart of the Process.

\begin{tabular}{|c|c|}
\hline Variables / Units & Data \\
\hline $\begin{array}{l}\text { Flux of water to boiler feed C- } \\
\mathrm{AZ},(\text { ton } / \mathrm{h})\end{array}$ & 70.0 \\
\hline $\begin{array}{l}\text { Flux of water to boiler feed C- } \\
\text { SZ, (ton/h) }\end{array}$ & 50.0 \\
\hline $\begin{array}{l}\text { Steam flow in each turbo } \\
\text { generator, }(\text { ton } / \mathrm{h})\end{array}$ & 18.0 \\
\hline $\begin{array}{l}\text { Steam flow in each turbo } \\
\text { generator, chipper and } \\
\text { shredder, (ton/h) }\end{array}$ & 13.2 \\
\hline $\begin{array}{l}\text { Inlet pressure in the boilers, } \\
(\mathrm{MPa})\end{array}$ & 3.00 \\
\hline $\begin{array}{l}\text { Output pressure in the boilers, } \\
\text { (MPa) }\end{array}$ & 2.25 \\
\hline $\begin{array}{l}\text { Inlet pressure in the turbo } \\
\text { mills, chipper and shredder, } \\
\text { (MPa) }\end{array}$ & 2.25 \\
\hline $\begin{array}{l}\text { Output pressure in the turbo } \\
\text { mills, chipper and shredder, } \\
\text { (MPa) }\end{array}$ & 0.25 \\
\hline $\begin{array}{l}\text { Inlet pressure in turbo } \\
\text { generators, }(\mathrm{MPa})\end{array}$ & 2.25 \\
\hline $\begin{array}{l}\text { Output pressure in turbo } \\
\text { generators, }(\mathrm{MPa})\end{array}$ & 0.25 \\
\hline Inlet temperature in boiler, $\left({ }^{\circ} \mathrm{C}\right)$ & 105 \\
\hline $\begin{array}{l}\text { Output temperature in boiler, } \\
\left({ }^{\circ} \mathrm{C}\right)\end{array}$ & 290 \\
\hline $\begin{array}{l}\text { Inlet temperature of the turbo } \\
\text { mills, chipper and shredder, } \\
\left({ }^{\circ} \mathrm{C}\right)\end{array}$ & 290 \\
\hline $\begin{array}{l}\text { Output temperature of the } \\
\text { turbo mills, chipper and } \\
\text { shredder, }\left({ }^{\circ} \mathrm{C}\right)\end{array}$ & 183 \\
\hline $\begin{array}{l}\text { Inlet temperature of turbine } \\
\text { generators, }\left({ }^{\circ} \mathrm{C}\right)\end{array}$ & 290 \\
\hline $\begin{array}{l}\text { Output temperature of turbine } \\
\text { generators, }\left({ }^{\circ} \mathrm{C}\right)\end{array}$ & 177 \\
\hline $\begin{array}{l}\text { Enthalpy at the entrance of the } \\
\text { boiler, }(\mathrm{kJ} / \mathrm{kg})\end{array}$ & 441.7 \\
\hline $\begin{array}{l}\text { Enthalpy at the exit of the } \\
\text { boiler, }(\mathrm{kJ} / \mathrm{kg})\end{array}$ & 2991 \\
\hline $\begin{array}{l}\text { Input Enthalpy of turbo } \\
\text { generators, }(\mathrm{kJ} / \mathrm{kg})\end{array}$ & 2991 \\
\hline $\begin{array}{l}\text { Output Enthalpy of turbo } \\
\text { generators, }(\mathrm{kJ} / \mathrm{kg})\end{array}$ & 2820 \\
\hline $\begin{array}{l}\text { Input Enthalpy on turbo mills, } \\
\text { chipper and shredder, }(\mathrm{kJ} / \mathrm{kg})\end{array}$ & 2991 \\
\hline $\begin{array}{l}\text { Output Enthalpy on turbo } \\
\text { mills, chipper and shredder, } \\
(\mathrm{kJ} / \mathrm{kg})\end{array}$ & 2832 \\
\hline $\begin{array}{l}\text { Energy efficiency } \\
\text { generator, } \%\end{array}$ & 39.5 \\
\hline $\begin{array}{l}\text { Energy efficiency turbo mills, } \\
\%\end{array}$ & 36.9 \\
\hline $\begin{array}{l}\text { Input Exergy in the boiler, } \\
(\mathrm{kJ} / \mathrm{kg})\end{array}$ & 41.4 \\
\hline $\begin{array}{l}\text { Output Exergy in the boiler, } \\
(\mathrm{kJ} / \mathrm{kg})\end{array}$ & 1012 \\
\hline $\begin{array}{l}\text { Input Exergy of turbo } \\
\text { generators, }(\mathrm{kJ} / \mathrm{kg})\end{array}$ & 1012 \\
\hline $\begin{array}{l}\text { Output Exergy of turbo } \\
\text { generators, }(\mathrm{kJ} / \mathrm{kg})\end{array}$ & 650.5 \\
\hline $\begin{array}{l}\text { Input Exergy on turbo mills, } \\
\text { chipper and shredder, }(\mathrm{kJ} / \mathrm{kg})\end{array}$ & 1012 \\
\hline $\begin{array}{l}\text { Output Exergy on turbo mills, } \\
\text { chipper and shredder, }(\mathrm{kJ} / \mathrm{kg})\end{array}$ & 654.4 \\
\hline $\begin{array}{l}\text { Exergy efficiency turbo } \\
\text { generator, } \%\end{array}$ & 47.3 \\
\hline $\begin{array}{l}\text { Exergy efficiency turbo mills, } \\
\%\end{array}$ & 44.2 \\
\hline
\end{tabular}

\section{RESULTS AND DISCUSSION}

The data in Table 1 will be simulated in COCO software and compared with the results found by Fiomari, in order to use the simulator to sugar energy units. A second simulation will be held where equipment-using steam will be replaced by electric motors, leaving only one steam-powered equipment. The third simulation is performed wherein the 
simulation of the second steam generator is replaced by a high pressure.

\section{Simulation 1}

This simulation was performed with the aim to validate the model generated by the software. The process and data presented in Fiomari were introduced into $\mathrm{COCO}$ simulator as it is shown in Fig. 4.

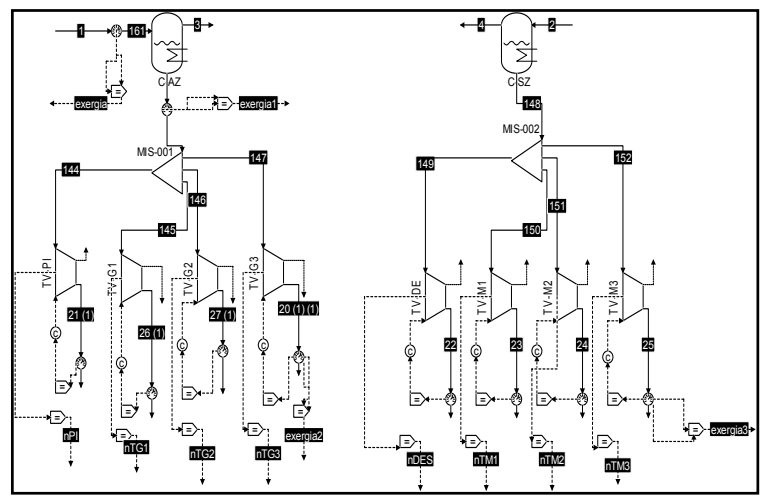

Figure 4. Energy sugar process using software COCO.

In Table 2 shows enthalpy and exergy values calculated by Fiomari and the $\mathrm{COCO}$ software. Simulated data in COCO software showed very similar results with those of Fiomari showing consistency.

Table 2. Comparison between calculated variables of COCO and Fiomari.

\begin{tabular}{|c|c|c|c|c|}
\hline \multirow{2}{*}{ Local } & \multicolumn{2}{|c|}{ FIOMARI } & \multicolumn{2}{|c|}{$\mathrm{COCO}$} \\
\hline & Enthalpy & Exergy & Enthalpy & Exergy \\
\hline $\begin{array}{l}\text { Input } \\
\text { boilers }\end{array}$ & 441.7 & 41.4 & 442.3 & 36.8 \\
\hline $\begin{array}{l}\text { Output of } \\
\text { boilers }\end{array}$ & 2991 & 1012 & 2993 & 1008 \\
\hline $\begin{array}{l}\text { Input of } \\
\text { Turbo } \\
\text { Generators }\end{array}$ & 2991 & 1012 & 2993 & 1008 \\
\hline $\begin{array}{l}\text { Output of } \\
\text { Turbo } \\
\text { Generators }\end{array}$ & 2820 & 650.5 & 2821 & 646 \\
\hline $\begin{array}{l}\text { Input of } \\
\text { turbo mills, } \\
\text { chipper and } \\
\text { shredder }\end{array}$ & 2991 & 1012 & 2993 & 1008 \\
\hline $\begin{array}{l}\text { Output of } \\
\text { turbo mills, } \\
\text { chipper and } \\
\text { shredder }\end{array}$ & 2832 & 654.4 & 2834 & 650.4 \\
\hline Unities & $\mathrm{kJ} / \mathrm{kg}$ & $\mathrm{kJ} / \mathrm{kg}$ & $\mathrm{kJ} / \mathrm{kg}$ & $\mathrm{kJ} / \mathrm{kg}$ \\
\hline
\end{tabular}

Table 3 shows the efficiencies calculated in COCO simulator and the Fiomari are presented and was verified that both results presented very close results of energetic and exegetic efficiencies.
Table 3. Comparison Fiomari and COCO efficiencies.

\begin{tabular}{lcccc}
\hline \multirow{2}{*}{ Local } & \multicolumn{2}{c}{ FIOMARI } & \multicolumn{2}{c}{ COCO } \\
\cline { 2 - 5 } & $\eta$ & $\Psi$ & $\eta$ & $\Psi$ \\
\hline $\begin{array}{l}\text { Turbo } \\
\text { Generators }\end{array}$ & 39.5 & 47.3 & 36.0 & 47.4 \\
\hline $\begin{array}{l}\text { Turbo } \\
\text { Mills }\end{array}$ & 36.9 & 44.2 & 33.5 & 44.0 \\
\hline
\end{tabular}

Thus, it is concluded that the simulation made on COCO software is validity comparing to the experimental data.

\section{Simulation 2}

In this simulation all turbines have been replaced by a single turbine for each steam generator. With this, we seek to assess whether the substitution of machinery moved to thermal energy by machines powered by electricity, leading to increased energy and exergetic efficiency.

Figure 5 shows the process flow diagram of COCO software for their replacements. It is emphasized that this approach is an approximation of the replacement of all steam engines powered by equivalent electricity. We believe that these electrically powered machines are ideal, i.e., it has $100 \%$ yield. This account should not have relevance of the comparison point of view that we are doing.

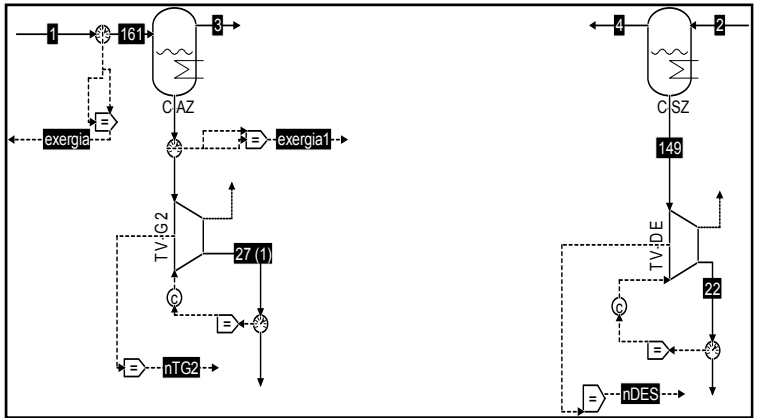

Figure 5. Flowchart of Energy process in $\mathrm{COCO}$ software in simulation 2 .

Table 4 shows presents the results simulated in software COCO. It is emphasized that these efficiencies if we consider that the electricity powered machines are not ideal, should be smaller. Still, the efficiencies presented in this simulation should be higher than in simulation 1 .

Table 4. COCO efficiencies for simulation 2.

\begin{tabular}{lcc}
\hline Local & $\eta(\%)$ & $\Psi(\%)$ \\
\hline Turbo Generators & 44.7 & 56.7 \\
Turbo Mills & 42.1 & 53.9 \\
\hline
\end{tabular}

\section{Simulation 3}

In the latter simulation the steam generator was replaced by a high pressure with the intention of 
seeking an improvement in efficiencies, as it is shown in Fig. 6.

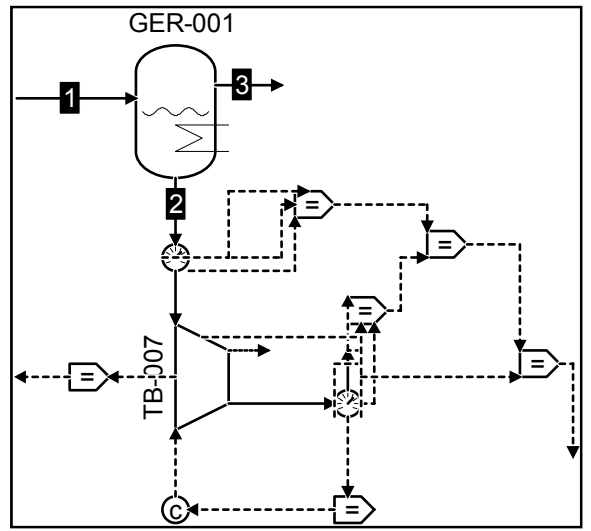

Figure 6. Flowchart of Energy process on $\mathrm{COCO}$ software in simulation 3 .

Table 5 shows it is seen that COCO software produce results with higher efficiencies and they are more satisfactory in the energy point of view.

Table 5. COCO efficiencies for simulation 3.

\begin{tabular}{lll}
\hline Local & $\eta(\%)$ & $\Psi(\%)$ \\
\hline Turbo Generators & 71.5 & 76.7 \\
\hline
\end{tabular}

\section{CONCLUSIONS}

The values found on simulation of the processes with free software $\mathrm{COCO}$ were very close to those presented in (Fiomari, 2004), so it can be considered that it is validated for this purpose.

Energy and exergy efficiency increased when thermal steam engines were, in simulated form, replaced by heat engines powered by electricity.

The increase of the steam pressure takes to an increase of energy and exergy efficiencies of the process.

\section{REFERENCES}

Bejan, A., 1988, Advanced Engineering Thermodynamic, John Wiley \& Sons.

Fiomari, M. C., 2004, Análise Energética e Exergética de uma Usina Sucroalcooleira do Oeste Paulista com Sistema de Cogeração de Energia em Expansão, Master Thesys, Ilha Solteira, São Paulo, Brasil. (in Portuguese)

Moran, M., and Shapiro, H., 2002, Princípios de Termodinâmica para Engenharia, LTC. (in Portuguese)

Neto, V. C., 2001, Análise de Viabilidade da Cogeração de Energia Elétrica em Ciclo Combinado com Gaseificação de Biomassa de Cana-de-Açúcar e Gás Natural, Master Thesys, Rio de Janeiro, Rio de Janeiro, Brasil. (in Portuguese) 